\title{
PENINGKATAN PRESTASI BELAJAR IPA MATERI ALAT PENCERNAAN MANUSIA DENGAN MENGGUNAKAN PUZZLE PADA SISWA KELAS V (LIMA) SDN 002 BELAKANG PADANG
}

\author{
ZULKIFLI \\ SDN 002 Belakang Padang, Kota Batam \\ 15zulkifli.74@gmail.com
}

\begin{abstract}
ABSTRAK
Penelitian ini bertujuan meningkatkan prestasi belajar IPA materi alat pencernaan manusia pada siswa kelas V SDN 002 Belakang Padang dengan menggunakan puzzle dan Subyek dalam penelitian ini adalah semua siswa kelas V(Lima) SDN 002 Belakang Padang yang berjumlah 28 siswa, terdiri dari perempuan 15 dan laki-laki 13.

Jenis penelitian yang digunakan peneliti adalah Penelitian Tindakan Kelas (PTK) dengan menggunakan puzzle alat pencernaan manusia. Data dalam penelitian ini diambil dengan metode pengamatan terhadap guru dan siswa dalam pembelajaran serta dengan menggunakan metode dokumentasi untuk mengambil data yang relevan. Berdasarkan hasil pengamatan dan pembahasan diperoleh bahwa: dengan menggunakan puzzle dapat meningkatkan prestasi belajar IPA materi alat pencernaan manusia pada siswa kelas V SDN 002 Belakang Padang tahun 2020/2021. Hasil tes siswa yang mengalami peningkatan persentase yaitu pada pra siklus saat pre test $10,71 \%$ yang tuntas terjadi peningkatan saat post test menjadi $25 \%$ berarti ada peningkatan sebanyak $14,29 \%$. Pada siklus I saat pre test $17,86 \%$ yang tuntas terjadi peningkatan saat post test menjadi $46,43 \%$ berarti ada peningkatan sebanyak $28,57 \%$. Pada siklus II saat pre test $32,14 \%$ yang tuntas terjadi peningkatan saat post test menjadi $71,43 \%$ berarti ada peningkatan sebanyak 39,28\%. Pada siklus III saat pre test $46,43 \%$ yang tuntas terjadi peningkatan saat post test menjadi $92,86 \%$ berarti ada peningkatan sebanyak $46,43 \%$.
\end{abstract}

Kata Kunci: Prestasi Belajar, Puzzle, Alat Pencernaan Manusia

\section{PENDAHULUAN}

Diamanatkan dalam UU No. 14 Tahun 2005 tentang Guru dan Dosen bahwa guru adalah pendidik profesional dengan tugas utama mendidik, mengajar, membimbing, mengarahkan, melatih, menilai, dan mengevaluasi peserta didik (Pasal 1). Mengacu pada isi UU No. 14 Tahun 2005 tersebut sangat jelas bahwa guru merupakan komponen yang penting dalam pendidikan (Suwandi, 2008: 11). Dalam mencapai tugas guru tersebut tidak semudah apa yang diharapkan, akan tetapi ada kendala-kendala yang sering muncul, baik itu dari guru sendiri maupun dari siswa. Hal tersebut seperti yang terjadi di SDN 002 Belakang Padang, khususnya pada siswa kelas V pada mata pelajaran Ilmu Pengetahuan Alam (IPA) materi alat pencernaan manusia yang prestasi belajarnya masih rendah.

Berdasarkan observasi menunjukkan bahwa kemampuan dalam menyerap materi pelajaran IPA materi Alat Pencernaan Manusia tergolong masih rendah. Hal ini dapat dilihat masih banyak siswa belum mencapai KKM yang telah ditentukan yaitu 70. Dari 
28 siswa yang tuntas dan dapat mencapai nilai KKM 70 hanya 5 siswa atau $17,86 \%$ dengan nilai rata-ratanya adalah 56,07, Mengetahui perolehan nilai hasil ulangan pada siswa kelas membuktikan bahwa prestasi belajar IPA, khususnya materi alat pencernaan manusia masih rendah. Padahal mata pelajaran IPA merupakan salah satu mata pelajaran yang penting, di mana materinya sebagian besar berhubungan dengan lingkungan dan manusia. Selain itu program IPA juga untuk menanamkan dan mengembangkan pengetahuan, keterampilan, sikap, rasa mencintai, dan mengagumi kebesaran Tuhan Yang Maha Esa. Hasil observasi yang peneliti lakukan, menemukan setidaknya 3 hal yang menyebabkan mengapa prestasi belajar di SDN 002 Belakang khususnya pada mata pelajaran IPA materi alat pencernaan manusia masih rendah. Pertama, pemahaman siswa tentang materi alat pencernaan masih relatif kurang. Kedua, siswa kurang bersemangat dalam proses belajar. Ketiga, guru dalam menyampaikan materi pembelajaran masih banyak dengan berceramah tanpa memanfaatkan media yang ada.

Berdasarkan kenyataan di atas, maka ketidakberhasilan bukan hanya terletak dari siswa akan tetapi juga berasal dari guru. Pada kenyatannya, guru sering menjelaskan pembelajaran dengan berceramah. Bahkan guru juga sering tidak menggunakan media dengan berbagai macam alasan, akibatnya siswa tidak tertarik untuk belajar, semangat siswa untuk belajar rendah, dan akhirnya pemahaman siswa tentang materi pelajaran juga rendah yang menyebabkan prestasi belajar menjadi tidak sesuai yang diharapkan. Banyak cara yang dapat dilakukan oleh guru, salah satunya dengan menggunakan media pembelajaran yang menarik dan berbeda. Guru dapat menggunakan berbagai macam media pembelajaran untuk mempermudah dalam menjelaskan mata pelajaran IPA, khususnya materi alat pencernaan manusia.

Maka penelitian ini di samping karena melihat nilai siswa yang masih rendah, peneliti juga ingin membuat sebuah terobosan baru dalam media pembelajaran, khususnya pada mata pelajaran IPA materi alat pencernaan manusia. Terobosan baru yang dimaksud oleh peneliti yaitu menggunakan sebuah puzzle. Puzzle memberi kemudahan bagi siswa dalam belajar. Puzzle ternyata dapat membantu anak belajar memecahkan masalah, mengasah ketekunan siswa. Dengan mencoba memasangkan kepingan berupa potongan-potongan gambar maka siswa dilatih untuk berpikir kreatif. Memadukan atau memasangkan kepingan puzzle membantu siswa dalam mengembangkan kemampuan berpikir (Saraswati, 2009: 108-109).

Penggunaan puzzle didasari pada sebuah kenyataan bahwa setiap siswa yang belajar membutuhkan situasi yang menyenangkan dan tidak terbebani termasuk kebosanan. Puzzle bisa memberikan kesempatan belajar yang banyak kepada siswa. Apabila hanya berdasarkan buku pegangan saja, maka akan menjemukan karena ada materi hafalan yang sulit dimengerti. Sehingga guru harus menghadirkan media pembelajaran yang menyenangkan dan menarik di dalam kelas sebagai upaya meningkatkan prestasi belajar siswa. Seperti yang diungkapkan oleh Hernawan (2008: 11.18-11.19) bahwa media pembelajaran adalah sarana untuk menyalurkan pesan atau informasi dari pengajar ke peserta didik atau sebaliknya. Penggunaan media pembelajaran memungkinkan terjadinya proses belajar pada diri peserta didik dan dapat meningkatkan efektivitas penggunaan media pembelajaran itu sendiri. Berdasarkan pengertian di atas, maka puzzle sebagai salah satu media pembelajaran 
yang menarik, di mana siswa bisa belajar sambil bermain dengan potongan-potongan gambar.

Peneliti menggunakan puzzle sebagai media pembelajaran karena memiliki beberapa kegunaan, antara lain menimbulkan semangat belajar dan menarik perhatian siswa sehingga dapat membantu mempercepat pemahaman dalam proses pembelajaran. Media puzzle yang digunakan berupa puzzle alat pencernaan manusia. Di mana saat pembelajaran berlangsung siswa akan menyusun potonganpotongan gambar alat pencernaan manusia pada tempat yang sesuai. Penggunaan puzzle alat pencernaan manusia diharapkan dapat meningkatkan prestasi belajar pada mata pelajaran IPA, terutama dalam materi alat pencernaan manusia. Berdasarkan latar belakang di atas, maka peneliti tertarik melakukan Penelitian Tindakan Kelas (PTK) dengan judul "Peningkatan Prestasi Belajar IPA Materi Alat Pencernaan Manusia dengan Menggunakan Puzzle pada Siswa Kelas V SDN 002 Belakang Padang.

\section{METODE PENELITIAN}

Penelitian ini dilakukan DI SDN 002 Belakang Padang dan Subjek Penelitian siswa kelas V di SDN 002 Belakang Padang yang berjumlah 28 siswa, terdiri dari 15 perempuan dan 13 laki-laki. Penelitian Tindakan Kelas (PTK) adalah jenis penelitian yang dilakukan oleh guru di kelasnya sendiri secara bersamaan dan bertahap dalam bentuk pelaksanaan tindakan tertentu sehingga terjadi peningkatan dan perbaikan proses pembelajaran di sekolah. Alasan peneliti menggunakan jenis Penelitian Tindakan Kelas karena peneliti terjun dan ikut berperan langsung dalam proses penelitian. Dalam penelitian ini kelas dijadikan sebagai obyek penelitan. Langkahlangkah awal dalam menyusun Penelitian Tindakan Kelas (PTK) yang dikemukakan oleh Arikunto dalam Suyadi (2010: 49-64 Tahap pertama dari PTK yaitu perencanaan. PTK tidak ubahnya seperti penelitian ilmiah lain yang selalu dipersiapkan secara matang. Langkah pertama adalah melakukan perencanaan secara matang dan teliti. Tahap kedua dari PTK yaitu pelaksanaan. Pelaksanaan adalah menerapkan apa yang telah direncanakan pada tahap satu, yaitu bertindak di kelas. Hendaknya perlu diingat bahwa tahap ini, tindakan harus sesuai dengan rencana, tetapi harus terkesan alamiah dan tidak direkayasa. Tahap ketiga dalam PTK yaitu pengamatan (observing). Observasi yang dimaksud dalam tahap III adalah pengumpulan data. Dengan kata lain, observasi adalah alat untuk memotret seberapa jauh efek tindakan telah mencapai sasaran. Tahap keempat dalam PTK yaitu refleksi. Refleksi adalah kegiatan untuk mengemukakan kembali apa yang telah dilakukan. Secara umum terdapat empat langkah dalam melakukan Penelitian Tindakan Kelas (PTK), antara lain: perencanaan, pelaksanaan, pengamatan, dan refleksi. Keempat tahapan ini saling terkait dan berkelanjutan. Hal ini merupakan ciri dari Penelitian Tindakan Kelas.

Bentuk instrumen yang dipakai untuk mempermudah penelitian ini dalam memperoleh data adalah Lembar pengamatan, Lembar soal tes, Pedoman dokumentasi, Silabus, Rencana Pelaksanaan Pembelajaran (RPP), sedang kan Teknik Pengumpulan Data menggunakan metode pengamatan/observasi, Dokumentasi. Analisis data adalah analisis data yang telah terkumpul guna mengetahui seberapa besar keberhasilan tindakan dalam penelitian untuk perbaikan belajar siswa (Suyadi, 2010: 85). Data yang telah terkumpul perlu dianalisis sesuai dengan tujuan penelitian dalam PTK untuk 
membuktikan kebenaran hipotesis. Benar tidaknya dugaan itu akan dibuktikan melalui data yang diperoleh dari lapangan. Sehingga dapat memberikan manfaat dalam meningkatkan kualitas pembelajaran sesuai dengan kondisi yang terjadi di dalam kelas. Dalam membuktikan hipotesis maka hasil penelitian akan dilakukan dengan analisis.

\section{HASIL DAN PEMBAHASAN}

\section{Deskripsi Hasil Penelitian Per Siklus}

Pra Siklus Pelaksanaan kegiatan mengajar pada pra siklus di kelas V dengan jumlah 28 siswa. Pada tahap pra siklus memberikan pandangan peneliti dalam mengambil langkah yang akan ditempuh pada tahap siklus I. Pada tahap ini, peneliti bertindak sebagai guru. Berdasarkan hasil penelitian pra siklus dapat disimpulkan bahwa siswa belum semangat dalam mengikuti pembelajaran dan siswa mengalami kesulitan dalam pembelajaran IPA materi alat pencernaan. Terbukti dengan nilai pre test dan post test pada pra siklus diperoleh data bahwa perbandingan nilai pre test dan post test menunjukkan peningkatan yang cukup baik. KKM yang telah ditentukan dari sekolah yaitu 70. Dari nilai pre test terdapat 3 atau 10,71\% siswa yang mencapai KKM dan nilai post test terjadi peningkatan menjadi 7 atau $25 \%$ siswa yang mencapai KKM. Nilai rata-rata siswa kelas V SDN 002 Belakang Padang pada post test pra siklus adalah 65,36 . Hasil tersebut menunjukkan bahwa ketuntasan siswa secara individu masih rendah. Sehingga akan dijadikan perbandingan untuk upaya peningkatan prestasi belajar menggunakan puzzle alat pencernaaan pada siklus I.

\section{Siklus I}

Pelaksanaan mengajar pada siklus I di kelas V dengan jumlah 28 siswa. Pada tahap ini, peneliti menyampaikan materi pembelajaran dengan menggunakan puzzle alat pencernaan manusia. Penelitian ini difokuskan pada peningkatan prestasi belajar siswa. Hasil penelitian pada siklus I ini, siswa tertarik dan semangat dalam mengikuti kegiatan pembelajaran. Akan tetapi, siswa belum fokus dalam materi pembelajaran. Sebagian dari mereka masih ramai sendiri, siswa masih takut dan bingung dalam menggunakan puzzle, serta menganggap bahwa puzzle pada pembelajaran hanya mainan saja yang tidak mengandung unsur pendidikan. Selain itu siswa masih belum berani untuk mengajukan dan menjawab pertanyaan. Meskipun demikian, ini merupakan langkah awal yang baik karena setidaknya siswa tertarik dan antusias belajar menggunakan puzzle alat pencernaan manusia. Pada Siklus I, siswa masih mengalami kesulitan dalam belajar IPA materi alat pencernaan manusia terlihat dari hasil tes formatif saat proses pembelajaran yang masih belum sesuai dengan apa yang diharapkan. Hasil tes yang belum sesuai harapan tersebut, dapat dibuktikan dengan perolehan nilai saat dilakukan pre test dan post test pada siklus, bahwa perbandingan nilai pre test dan post test menunjukkan peningkatan yang baik. KKM yang telah ditentukan dari sekolah yaitu 70. Dari nilai pre test terdapat 5 siswa/17,86\% yang mencapai KKM dan nilai post test terjadi peningkatan menjadi 13 siswa/46,43\% yang mencapai KKM. Nilai rata-rata siswa kelas V SDN 002 Belakang Padang pada post test siklus I adalah 72,29. Berdasarkan data tersebut dapat ditarik kesimpulan bahwa pada siklus I siswa mulai tertarik, karena guru menggunakan media baru dalam 
pembelajaran. Secara garis besar siklus I berjalan dengan baik, hal ini harus dijadikan suatu yang harus dibenahi dalam pelaksanaan siklus II.

\section{Siklus II}

Pelaksanaan mengajar pada siklus II dilaksanakan di kelas V dengan jumlah 28 siswa. Pada tahap ini, peneliti bertindak sebagai guru. Peneliti menyajikan materi dengan menggunakan puzzle alat pencernaan manusia. Pada siklus II ini, siswa memperhatikan intruksi guru, suasana kelas mulai efektif, dan siswa mulai berani mengajukan pertanyaaan. Selain itu masih ada beberapa siswa yang masih kurang percaya diri dan masih takut dalam menggunakan puzzle. Berdasarkan hasil penelitian siklus II dapat disimpulkan bahwa siswa lebih semangat dalam mengikuti pembelajaran, meskipun masih ada beberapa siswa berbicara dengan teman sebangkunya yang membuat siswa belum fokus sepenuhnya terhadap materi yang diajarkan. Seperti pada tindakan kelas pra siklus dan siklus I, peneliti juga memberikan tes formatif kepada siswa untuk mengukur pemahaman dan mengetahui tingkat prestasi belajar siswa. Tingkat pencapaian terbukti dengan hasil nilai pre test dan post test pada siklus II diperoleh data bahwa perbandingan nilai pre test dan post test menunjukkan peningkatan yang sangat baik. Berpedoman pada Kriteria Ketuntasan Minimal (KKM) yang telah ditentukan dari sekolah yaitu 70, maka diketahui yaitu nilai pre test terdapat 9 siswa atau 32,14\% yang mencapai KKM dan nilai post test mengalami peningkatan menjadi 20 siswa atau 71,43\% yang mencapai 81 KKM. Nilai rata-rata siswa kelas V SDN 002 Belakang Padang pada post test siklus II adalah 73,75. Dari data di atas dapat ditarik kesimpulan bahwa pada siklus II siswa lebih tertarik dan lebih semangat dalam belajar. Secara garis besar siklus II berjalan dengan baik dan pembelajaran mulai efektif. Akan tetapi peneliti masih perlu melanjutkan penelitian pada tindakan kelas siklus III karena belum sesuai dengan hasil yang diharapkan yaitu ketuntasan individu siswa $80 \%$.

\section{Siklus III}

Pelaksanaan mengajar pada siklus III dilaksanakan di kelas V dengan jumlah 28 siswa. Pada tahap ini, peneliti bertindak sebagai guru. Peneliti menyajikan materi dengan menggunakan puzzle alat pencernaan manusia. Pada siklus III hampir semua siswa memperhatikan materi pembelajaran yang disampaikan guru, hal ini dikarenakan guru sudah terbiasa menyampaikan materi pembelajaran dengan menggunakan puzzle alat pencernaan manusia. Selain itu penggunaan puzzle yang dilaksanakan pada siklus III, siswa semakin semangat dan percaya diri dalam menggunakan puzzle. Kelas menjadi lebih tenang (kondusif). Siswa juga semakin berani untuk menjawab dan mengajukan pertanyaan. Seperti pada pra siklus, siklus I, dan siklus II, peneliti juga memberikan tes formatif sebagai pengukur prestasi belajar siswa. Hasil 82 dari tes yang telah dilakukan pada siklus III, dibuktikan dengan data nilai pre test dan post test bahwa perbandingan nilai pre test dan post test menunjukkan peningkatan yang sangat memuaskan. Dari nilai pre test terdapat 13 siswa atau 46,43\% yang mencapai KKM dan nilai post test terjadi peningkatan menjadi 26 siswa 83 atau 92,86\% yang mencapai KKM. Nilai rata-rata siswa kelas V SDN 002 Belakang Padang pada post test siklus III adalah 81,25 . Nilai dari siklus III mengalami peningkatan yang baik dibandingkan 
dengan nilai pada siklus II. Pada siklus III masih ada 2 siswa yang belum tuntas. Siswa ini adalah siswa yang sama pada pra siklus, siklus I, dan siklus II. Siswa yang belum tuntas tersebut sebenarnya dari setiap siklus mengalami peningkatan, akan tetapi belum dapat mencapai KKM yang ditentukan. Selain itu dari guru kelas juga mengatakan bahwa 2 siswa tersebut yang bernama Ndari Tika Safitri dan Sri Hariyati memang memerlukan bimbingan belajar yang lebih lanjut lagi. Secara garis besar pelaksanaan siklus III berjalan baik. Berdasarkan nilai siswa yang diperoleh berarti terdapat peningkatan prestasi belajar melalui penggunaan puzzle alat pencernaan manusia. Sehingga peneliti merasa tidak perlu untuk melanjutkan ke pelaksanaan berikutnya.

Data Peningkatan Prestasi Belajar Per Siklus Berdasarkan hasil penelitian yang telah dilakukan, maka peneliti memperoleh data dari hasil prestasi belajar siswa pada setiap siklusnya. Pelaksanaan pra siklus, di mana peneliti belum menggunakan puzzle alat pencernaan manusia, akan tetapi pada siklus I, siklus II dan siklus III peneliti sudah menggunakan puzzle alat pencernaan manusia. Dipaparkan sebagai berikut:

Tabel 1. Data Peningkatan Prestasi Belajar Per Siklus

\begin{tabular}{|l|l|l|l|}
\hline \multicolumn{1}{|c|}{ Kegiatan } & \multicolumn{1}{|c|}{ Pre test } & \multicolumn{1}{c|}{ Post test } & Peningkatan \\
\hline Pra siklus & 3 siswa/10,71\% & 7 siswa/25\% & 4 siswa/14,29\% \\
\hline Siklus I & 5 siswa/17,86\% & 13 siswa/46,43\% & 8 siswa/28,57\% \\
\hline Siklus II & 9 siswa/32,14\% & 20 siswa/71,43\% & 1 siswa/39,28\% \\
\hline Siklus III & 13 siswa/46.43\% & 26 siswa/92,86\% & 13 siswa/46,43\% \\
\hline
\end{tabular}

Berdasarkan data peningkatan prestasi belajar per siklus di atas dapat diketahui bahwa prestasi belajar siswa dalam mata pelajaran IPA dengan menggunakan puzzle alat pencernaan manusia dari setiap siklus mengalami peningkatan yang cukup baik. Prestasi belajar siswa mengalami peningkatan yang baik di setiap siklusnya. Hasil penelitian yang diperoleh tersebut, menunjukkan bahwa meningkatnya prestasi belajar ini dipengaruhi karena penggunaan puzzle alat pencernaan manusia.

Pembelajaran dengan menggunakan puzzle membuat siswa menjadi tertarik sehingga tumbuh semangat belajar yang tinggi. Proses pembelajaran IPA menggunakan puzzle alat pencernaan manusia juga menjadikan suasana yang menyenangkan. Selain itu, saat diterapkannya pembelajaran menggunakan puzzle kepada siswa kelas V SDN 002 Belakang Padang, peneliti mengamati ternyata antara siswa satu dengan yang lain dapat memahami pentingnya sebuah kebersamaan hidup. Hal ini selaras dengan pendapat Suyadi (2010: 321) bahwa puzzle juga memiliki makna filosofis.

Makna filosofisnya bahwa kebersamaan hidup itu dirangkai dari berbagai perbedaan. Berbeda dalam hal ini adalah berbeda yang berbentuk sehingga dapat mengisi kekosongan yang dibutuhkan dengan tepat dan pas. Berbagai bentuk potongan puzzle merupakan simbol dari keanekaragaman yang dipadukan sesuai dengan posisi 
masing-masing, di mana akan membentuk pola atau tatanan hidup yang rahmatan lil alamin.

\section{KESIMPULAN}

Berdasarkan hasil Penelitian Tindakan Kelas (PTK) yang telah dilakukan dapat disimpulkan bahwa dengan menggunakan puzzle dapat meningkatkan prestasi belajar IPA materi alat pencernaan manusia pada siswa kelas V SDN 002 Belakang Padang,. Hal ini dibuktikan dengan peningkatan prestasi belajar siswa yang ditunjukkan dengan jumlah siswa yang tuntas dari setiap siklusnya yaitu pada pra siklus saat pre test $10,71 \%$ yang tuntas terjadi peningkatan saat post test menjadi $25 \%$ berarti ada peningkatan sebanyak $14,29 \%$. Pada siklus I saat pre test $17,86 \%$ yang tuntas terjadi peningkatan saat post test menjadi $46,43 \%$ berarti ada peningkatan sebanyak $28,57 \%$. Pada siklus II saat pre test $32,14 \%$ yang tuntas terjadi peningkatan saat post test menjadi $71,43 \%$ berarti ada peningkatan sebanyak 39,28\%. Pada siklus III saat pre test 46,43\% yang tuntas terjadi peningkatan saat post test menjadi $92,86 \%$ berarti ada peningkatan sebanyak $46,43 \%$.

Saran yang dapat disampaikan Berdasarkan kesimpulan di atas, hal-hal yang sebaiknya dilakukan oleh guru maupun sekolah untuk meningkatan prestasi belajar pada siswa, maka yang harus dilakukan adalah bagi Guru sebaiknya memperbanyak wawasan dan pengetahuan baru, salah satunya dengan mengembangkan terobosan baru tentang media yang digunakan dalam mengajar. Siswa menjadi lebih tertarik dan semangat dalam mengikuti proses pembelajaran. Bagi Siswa berusaha meningkatkan belajar yang lebih baik lagi agar penguasaan materi dapat maksimal dan prestasi belajar lebih meningkat. Bagi Sekolah dalam am hal ini adalah sebagai penyelenggara pendidikan sebaiknya meningkatkan pembinaan pada guru. Dengan adanya pembinaan diharapkan dapat menjadi dorongan menjadi lebih baik lagi dalam memberikan pelayanan kepada siswa.

\section{DAFTAR PUSTAKA}

Abtokhi, A. 2008. SAINS untuk PGMI dan PGSD. Malang: UIN-Malang Press. Ahmadi, A., Widodo S. 2004. Psikologi Belajar. Jakarta: PT Rineka Cipta.

Arifin, Z. 2011. Evaluasi Pembelajaran. Bandung: PT Remaja Rosdakarya.

Azmiyawati, C., Wigati H.O., \& Rohana K. 2008. IPA Salingtemas 5. Jakarta: Pusat Perbukuan, Departemen Pendidikan Nasional.

Basrowi, Suwandi. 2008. Prosedur Penelitian Tindakan Kelas. Bandung: Ghalia Indonesia. Depdiknas. 2007.

Dedi D. 2010. Mengenal Penelitian Tindakan Kelas. Jakarta: PT Indeks. Maslikah,

Garnida, D., Rudy B. 2002. Pendidikan IPA Madrasah Ibtidaiyah. Jakarta: Ditjen Binbaga Departemen Agama. Hadiat. 1996. Alam Sekitar Kita. Jakarta: PT Ciptawidya Swara.

Haryanto. 2004. SAINS untuk Sekolah Dasar Kelas V. Jakarta: Erlangga. 
Hernawan, A.H., dkk. 2008. Pengembangan Kurikulum dan Pembelajaran. Jakarta: Universitas Terbuka. Iskandar, R.Y. 2009. Permainan yang Meningkatkan Kecerdasan Anak Modren \& Tradisional. Jakarta: Laskar Aksara.

Kunandar. 2011. Langkah Mudah Penelitian Tindakan Kelas Sebagai Pengembangan Profesi Guru. Jakarta: PT RajaGrafindo Persada.

Mulyasa. 2009. Praktik Penelitian Tindakan Kelas. Bandung: PT Remaja Rosdakarya. Peni S. 2009. Ilmu Alamiah Dasar. Yogyakarta: Mitra Cendekia. 